Article

\title{
The Influence of Emotional Intelligence on Leadership Style at Integrated Service Unit (UPT) Regional Revenue Management in Pematangsiantar
}

\author{
Julyanthry, Efendi, Marisi Butarbutar, Melki Novita Simanjuntak \\ Sekolah Tinggi Ilmu Ekonomi Sultan Agung, Pematangsiantar, Indonesia
* Correspondence: yoe.lianthry@gmail.com
}

How to cite this paper: Julyanthry, Efendi, Butarbutar, M., \& Simanjuntak, M. N. (2021). The Influence of Emotional Intelligence on Leadership Style at Integrated Service Unit (UPT) Regional Revenue Management in Pematangsiantar. Universal Journal of Business and Management, 1(1), 1-12. DOI:

https://doi.org/10.31586/ujbm.2021.0 10101 Retrieved from https://www.scipublications.com/journal/index.php/ujbm/article/view/40

Received: April 19, 2021 Accepted: June 07, 2021 Published: June 08, 2021

Copyright: (c) 2021 by the authors. Submitted for possible open access publication under the terms and conditions of the Creative Commons Attribution (CC BY) license (http://creativecommons.org/licenses /by/4.0/).

\begin{abstract}
The purpose of this research is: 1. To determine the description of emotional intelligent and leadership style in the Integrated Service Unit (UPT) Regional Revenue Management in Pematangsiantar. 2. To determine the influence of emotional intelligent to leadeship style in the Integrated Service Unit (UPT) Regional Revenue Management in Pematangsiantar. The research uses literature research design and field research. The population in this study were all administrative employee at in the Integrated Service Unit (UPT) Regional Revenue Management in Pematangsiantar, emounted to 42 employees. The type of data used are qualitative data and quantitative data. Sources of data used are primary and secondary. The data were collected through questionnaries, interviews and documentation. Test of instrument used with validity test and reliability test. The analysis technique used are normality test, qualitative descriptive analysis and quantitative descriptive analysis. The result of this study can be summarized as follows: 1. Emotional intelligent and leadership style are good. 2. Emotional intelligent have positive effect on leadership style. 3. Emotional intelligent heve moderately corelation with leadership style then the level of leadership style can be explained by emotional intelligent. 4 . H0 is rejected, meaning that emotional intelligent has positive and significantly to leadership style. The suggestions of this research are: 1 . To make leadership style, the leaders should be provided opportunities for employee to be more independently in making decisions both individually or in grups. 2. To enhance emotional intelligent, the leaders should record data of employee to know their skill, knowledge or work experience
\end{abstract}

Keywords: Emotional intelligent, Management, Leadership style, UPT

\section{Introduction}

Humans are an important asset of an organization whose existence is still difficult to replace. Even though the development of the world is very advanced, several things in humans still cannot be automated, let alone replaced [1,5]. This is because it requires the ability to socialize, communicate and make decisions. A person's ability and style in leading and dealing with different personalities from subordinates and other individuals he meets cannot be automated [2]. Some of the things mentioned above still require the ability to manage emotional intelligence, not just intellectual intelligence [8]. The right emotional management skills so that each individual organization can work optimally. No exception with the UPT Revenue Management in Pematangsiantar always strives to produce optimal results. UPT Regional Revenue Management in Pematangsiantar is one of the government agencies in charge of providing services to the community. UPT Regional Revenue Management in Pematangsiantar is one of the agencies that provides income to the government through its functions. The functions of the UPT Regional Revenue Management in Pematangsiantar include issuing Vehicle Registration Certificates (STNK), determining the amount of Motor Vehicle Tax (PKB), Transfer of Vehicle Name Fees (BBNKB) and managing the Mandatory Road Traffic Accident Fund Contribution (SWDKLLJ). 
Everyone certainly has their own unique characteristics in their leadership. Applying the right leadership style, leaders can direct their subordinates to achieve their goals well and optimally $[3,6]$. There are several types of leadership styles, namely autocratic leadership styles, democratic leadership styles and control-free leadership styles.

The phenomenon that occurs in the UPT Regional Revenue Management in Pematangsiantar is that the type of democratic leadership style is not optimal because the head of the UPT does not accept opinions or suggestions from subordinates so that employees are not given the opportunity to provide input or advice to the head of the UPT in decision making. And the phenomenon of the type of control-free leadership style is not optimal, seen from the lack of independence of employees in making decisions both individually / in work groups because of too much interference in every employee decision making. Leadership style as a person's behavior in leading employees certainly cannot be separated from the influence of one's intelligence.

This is in line with Darlita's research (2019: 89) which states that there is an influence between emotional intelligence on leadership style $[4,13]$. Emotional intelligence is the ability for a person to feel and understand effectively the emotional sensitivity of oneself and others in order to establish good relationships with others so that they can achieve the common goals that have been set initially effectively and efficiently [10]. The dimensions of emotional intelligence are self-awareness, self-regulation, motivation, empathy and social skills [12]. The phenomenon of emotional intelligence that occurs in the Pematangsiantar Regional Revenue Management Unit can be seen from the dimension of selfawareness that needs to be improved, this can be seen from the leadership that they do not fully know the strengths possessed by employees because the leadership still misplaces employees and does not match the abilities and knowledge of employees.

In addition, the phenomenon that occurs in the dimension of self-regulation with indicators of maintaining honesty norms needs to be considered, this is because there are still employees who accept other people's vehicle tax management by using the services of brokers. From the description above, it can be seen that there is a gap between the phenomena and the existing theory of reality in emotional intelligence on leadership styles. Therefore, the researchers are interested in conducting this research.

\section{Research Methodology}

\subsection{Research Design}

In this study, the research design of this study was qualitative research. Qualitative research is an approach for exploring meaning ascribe to human problem. Human have problems in different perspective when read news, then the research collected data in form of words [7, 9]

The research design used by the researchers is as follows:

\section{Library research (library research)}

Research conducted by collecting data. The method is to read, search for information through electronic devices (browsing), study scientific books, lecture notes and other references related to research titles.

\section{Field research (field research)}

The research was conducted by collecting data from interviews with employees of the UPT Regional Revenue Management in Pematangsiantar.

\subsection{Object of Research}

The object of research in this case is the staff of the Pematangsiantar Regional Revenue Management Unit.

\subsection{Time and Place of Research}

1. Research time: The time of this research is planned for approximately five months from October 2020 to February 2021 
2. Research Place: The place to do the research is the UPT Regional Revenue Management in Pematangsiantar which is located at Jalan Sangnawaluh No. 37-A Pematangsiantar, Tel. (0622) 7552345 - Fax. (0622) 7550345.

\subsection{The scope of Research}

The scope of this research discusses the emotional intelligence and leadership style of the UPT Regional Revenue Management in Pematangsiantar. Where the dimensions of emotional intelligence are self-awareness, self-regulation, motivation, empathy and social skills. While the dimensions of leadership style, namely autocratic leadership style, democratic leadership style and free control leadership style [11]

\subsection{Operational Definition of Variables}

The operational definition is the drawing of boundaries that better explain the specific features of a concept. The goal is to create a measuring instrument in accordance with the variables that have been defined with the concepts that have been available [9]. The operational definitions for each variable in the study are described in the following Table 1.

Table 1. Operational Definition of Variables

\begin{tabular}{|c|c|c|c|c|}
\hline No. & Variable & Dimension & Indicator & Scale \\
\hline \multirow[t]{5}{*}{1} & \multirow{5}{*}{$\begin{array}{l}\text { Emotional intelligence is } \\
\text { the ability to motivate } \\
\text { oneself, to withstand } \\
\text { frustration, to control } \\
\text { impulses, to dislike ex- } \\
\text { cessively, to control } \\
\text { moods, to keep the bur- } \\
\text { den of stress from crip- } \\
\text { pling the ability to think } \\
\text { and to empathize and } \\
\text { pray. }\end{array}$} & $\begin{array}{l}\text { Self-awareness is the ability to con- } \\
\text { trol and understand our own } \\
\text { moods, emotions and impulses and } \\
\text { their effects on others. }\end{array}$ & $\begin{array}{l}\text { Recognizing your own emo- } \\
\text { tions. } \\
\text { Knowing your own strength. } \\
\text { Having confidence in one's own } \\
\text { abilities }\end{array}$ & \multirow[t]{5}{*}{ Likert } \\
\hline & & $\begin{array}{l}\text { Self-regulation is the ability to con- } \\
\text { trol impulses and moods and think } \\
\text { before acting. }\end{array}$ & $\begin{array}{l}\text { Hold back your emotions. } \\
\text { Maintain the norms of honesty. } \\
\text { Innovation by receiving new in- } \\
\text { formation openly. }\end{array}$ & \\
\hline & & $\begin{array}{l}\text { Self-motivation is a tendency to be } \\
\text { full of enthusiasm and constantly } \\
\text { strive for goals. }\end{array}$ & $\begin{array}{l}\text { Encouragement to be better. } \\
\text { Adjusting to the target group or- } \\
\text { ganization. } \\
\text { Persistence in fighting for fail- } \\
\text { ure. }\end{array}$ & \\
\hline & & $\begin{array}{c}\text { Empathy is the ability to under- } \\
\text { stand the emotions and reactions of } \\
\text { others. }\end{array}$ & $\begin{array}{l}\text { Awareness of other people's } \\
\text { feelings. } \\
\text { Understanding the emotional } \\
\text { state in the group. } \\
\text { Creating opportunities through } \\
\text { association with a wide variety } \\
\text { of people }\end{array}$ & \\
\hline & & $\begin{array}{l}\text { Social skills are the ability to build, } \\
\text { maintain interpersonal networks } \\
\text { and build good relationships. }\end{array}$ & $\begin{array}{c}\text { Conveying messages clearly to } \\
\text { others. } \\
\text { Cooperating with others to } \\
\text { achieve common goals. } \\
\text { The team's ability to create } \\
\text { group synergy in fighting for } \\
\text { common goals. }\end{array}$ & \\
\hline 2 & $\begin{array}{l}\text { Leadership style is a } \\
\text { leader's way of influenc- } \\
\text { ing subordinates }\end{array}$ & $\begin{array}{l}\text { Autocratic leadership style, which } \\
\text { is a leadership style that only puts } \\
\text { power in the hands of one person. }\end{array}$ & $\begin{array}{l}\text { Determination of policy. } \\
\text { The technique of assigning ac- } \\
\text { tivities. }\end{array}$ & Likert \\
\hline
\end{tabular}




\begin{tabular}{|c|c|c|c|c|}
\hline No. & Variable & Dimension & Indicator & Scale \\
\hline & & & Dictating work assignments. & \\
\hline & & $\begin{array}{l}\text { Democratic leadership style is the } \\
\text { style of a leader who views and } \\
\text { places his subordinates as a subject } \\
\text { who has a personality with various } \\
\text { aspects ranging from will, will, } \\
\text { ability, ideas, opinions, creativity, } \\
\text { different initiatives and is respected } \\
\text { and channeled fairly }\end{array}$ & $\begin{array}{l}\text { Helping make decisions. } \\
\text { Freedom to give suggestions or } \\
\text { input. } \\
\text { Distribution of tasks. }\end{array}$ & \\
\hline & & $\begin{array}{l}\text { Control-free leadership style is a } \\
\text { style that is carried out by giving } \\
\text { full freedom to the person being led } \\
\text { in making decisions and carrying } \\
\text { out activities according to their re- } \\
\text { spective wishes and interests. }\end{array}$ & $\begin{array}{l}\text { Freedom of work. } \\
\text { Freedom in making decisions. } \\
\text { Freedom to organize yourself. }\end{array}$ & \\
\hline
\end{tabular}

Source: data management (2021)

\subsection{Population and Sample}

The population in this study were all employees at the UPT Regional Revenue Management in Pematangsiantar totaling 42 people $(\mathrm{N}=42)$. Where the withdrawal sample is all employees as many as 42 people using a saturated sample.

\subsection{Type of Data}

The types of data used in this study are quantitative data and qualitative data.

1. Qualitative data

Qualitative data is data in the form of sentences, words or pictures, such as: general description, organizational structure and responsibilities of each position contained in the UPT Regional Revenue Management in Pematangsiantar.

\section{Quantitative data}

Quantitative data is research data in the form of numbers or scoring qualitative data. Quantative data were obtained from data on the number of employees and data obtained from questionnaires.

\subsection{Data Source}

In this study, the data sources used were as follows:

1. Primary data

Primary data is basic data or data obtained directly from the first source in the form of interviews or filling out questionnaires at the UPT Regional Revenue Management in Pematangsiantar.

\section{Secondary data}

Secondary data is data obtained from various sources that are considered relevant to research. In this study, secondary data were obtained from library books and the internet related to research problems.

\subsection{Technique of Data Collection}

Data collection techniques are the methods used by researchers to collect data. The data collection techniques used are:

\section{Questionnaire method}

The questionnaire method is a data collection technique that is carried out by giving a set of written questions to the respondent to be answered. The measurement scale in this study is a Likert scale gradient from the lowest to the highest expressed in the form of words in the form of Table 2: 
Table 2. Likert Scale

\begin{tabular}{|c|c|}
\hline Question Scale & Skala Likert \\
\hline Very Good & 5 \\
\hline Good & 4 \\
\hline Satisfy & 3 \\
\hline Bad & 2 \\
\hline Very bad & 1 \\
\hline
\end{tabular}

Source: Sugiyono (2013:93)

\section{Interview method}

The interview method is a data collection technique by conducting direct interviews with respondents related to the object of research

\section{Documentation method}

The documentary method is a method used to obtain data from books and theoretical literature related to this research.

\subsection{Data Collection Tools}

Data collection tools used by the author are in the form of notebooks, stationery, questionnaires, internet networks and laptops / computers.

\subsection{Research Instrument Test}

The instrument test is one of the tools used in quantitative research by using the instrument test, we can find out the quality of the data to be used [9]. The research instrument test was carried out for primary data consisting of validity and reliability tests. The validity and reliability tests were carried out on the comparison agency, namely the Department of Manpower of North Sumatra Province, UPT Simalungun Manpower Training with a sample of 30 people.

\subsubsection{Test the validity}

Validity test is a test conducted to determine the accuracy and accuracy of a measurement instrument in performing its measuring function. If the correlation coefficient is equal to 0.3 or more (at least 0.3 ) it is declared valid using the help of SPSS version 21.

Table 3. Validity Test Results

\begin{tabular}{|c|c|c|c|c|c|}
\hline \multicolumn{2}{|c|}{ Variables } & $\begin{array}{l}\text { Instrument } \\
\text { Items }\end{array}$ & $\mathbf{R}_{\text {calculation }}$ & $\mathbf{r}_{\text {krisis }}$ & Notes \\
\hline \multirow{16}{*}{$\begin{array}{l}\text { Emotional In- } \\
\text { telligence }\end{array}$} & \multirow{3}{*}{ Self-awareness } & X.1 & 0,348 & 0,3 & Valid \\
\hline & & $\mathrm{X} .2$ & 0,583 & 0,3 & Valid \\
\hline & & X.3 & 0,440 & 0,3 & Valid \\
\hline & \multirow{3}{*}{ Self Regulation } & X.4 & 0,348 & 0,3 & Valid \\
\hline & & X.5 & 0,613 & 0,3 & Valid \\
\hline & & X.6 & 0,582 & 0,3 & Valid \\
\hline & \multirow{3}{*}{ Self-motivation } & $X .7$ & 0,389 & 0,3 & Valid \\
\hline & & X.8 & 0,352 & 0,3 & Valid \\
\hline & & X.9 & 0,582 & 0,3 & Valid \\
\hline & \multirow{3}{*}{ Empathy } & X.10 & 0,582 & 0,3 & Valid \\
\hline & & X.11 & 0,376 & 0,3 & Valid \\
\hline & & X.12 & 0,797 & 0,3 & Valid \\
\hline & \multirow{4}{*}{ Social Skills } & X.13 & 0,936 & 0,3 & Valid \\
\hline & & X.14 & 0,797 & 0,3 & Valid \\
\hline & & X.15 & 0,348 & 0,3 & Valid \\
\hline & & $\mathrm{Y} 1.1$ & 0,585 & 0,3 & Valid \\
\hline
\end{tabular}




\begin{tabular}{|c|c|c|c|c|c|}
\hline \multirow{8}{*}{$\begin{array}{l}\text { Leadership } \\
\text { Styles }\end{array}$} & \multirow{2}{*}{$\begin{array}{c}\text { Autocratic leader- } \\
\text { ship style }\end{array}$} & Y1.2 & 0,463 & 0,3 & Valid \\
\hline & & Y1.3 & 0,446 & 0,3 & Valid \\
\hline & \multirow{3}{*}{$\begin{array}{l}\text { Democratic lead- } \\
\text { ership style }\end{array}$} & Y1.4 & 0,797 & 0,3 & Valid \\
\hline & & Y1.5 & 0,845 & 0,3 & Valid \\
\hline & & Y1.6 & 0,936 & 0,3 & Valid \\
\hline & \multirow{3}{*}{$\begin{array}{l}\text { Control-freedom } \\
\text { leadership style }\end{array}$} & Y1.7 & 0,845 & 0,3 & Valid \\
\hline & & Y1.8 & 0,912 & 0,3 & Valid \\
\hline & & Y1.9 & 0,439 & 0,3 & Valid \\
\hline
\end{tabular}

Source: Results of questionnaire processing using SPSS version 21 (2021)

Based on the test in Table 3, the validity test results show that the calculated $r$ value of all indicators is greater than critical $r$, it can be concluded that all indicators of the variables in this study are valid.

\subsubsection{Reliability test}

Reliability test is a test used to measure the stability of the indicators of a variable. The questionnaire is declared reliable if a person's answer to the question is stable or consistent over time with the help of SPSS version 21. A variable is said to be reliable if it gives a Chronbach's Alpha value> 0.70 .

Table 4. Reliability Test Results

\begin{tabular}{|c|c|c|c|c|c|}
\hline \multicolumn{2}{|c|}{ Variables } & Instrume & $\begin{array}{l}\text { Cronbach's } \\
\text { Alpha if item }\end{array}$ & rkrisis & Notes \\
\hline \multirow{15}{*}{$\begin{array}{l}\text { Emotional In- } \\
\text { telligence }\end{array}$} & \multirow{3}{*}{ Self-awareness } & X.1 & 0,812 & 0,70 & Reliable \\
\hline & & $X .2$ & 0,811 & 0,70 & Reliable \\
\hline & & X.3 & 0,811 & 0,70 & Reliable \\
\hline & \multirow{3}{*}{ Self Regulation } & X.4 & 0,812 & 0,70 & Reliable \\
\hline & & X.5 & 0,811 & 0,70 & Reliable \\
\hline & & X.6 & 0,812 & 0,70 & Reliable \\
\hline & \multirow{3}{*}{ Self-motivation } & X.7 & 0,812 & 0,70 & Reliable \\
\hline & & X.8 & 0,812 & 0,70 & Reliable \\
\hline & & X.9 & 0,812 & 0,70 & Reliable \\
\hline & \multirow{3}{*}{ Empathy } & X.10 & 0,812 & 0,70 & Reliable \\
\hline & & X.11 & 0,812 & 0,70 & Reliable \\
\hline & & X.12 & 0,811 & 0,70 & Reliable \\
\hline & \multirow{3}{*}{ Social Skills } & X.13 & 0,810 & 0,70 & Reliable \\
\hline & & X.14 & 0,811 & 0,70 & Reliable \\
\hline & & X.15 & 0,812 & 0,70 & Reliable \\
\hline \multirow{9}{*}{$\begin{array}{l}\text { Leadership } \\
\text { Styles }\end{array}$} & \multirow{3}{*}{$\begin{array}{l}\text { Autocratic leadership } \\
\text { style }\end{array}$} & $\mathrm{Y} 1.1$ & 0,812 & 0,70 & Reliable \\
\hline & & Y1.2 & 0,812 & 0,70 & Reliable \\
\hline & & Y1.3 & 0,812 & 0,70 & Reliable \\
\hline & \multirow{3}{*}{$\begin{array}{c}\text { Democratic leadership } \\
\text { style }\end{array}$} & Y1.4 & 0,811 & 0,70 & Reliable \\
\hline & & $\mathrm{Y} 1.5$ & 0,811 & 0,70 & Reliable \\
\hline & & Y1.6 & 0,810 & 0,70 & Reliable \\
\hline & \multirow{3}{*}{$\begin{array}{l}\text { Control-freedom lead- } \\
\text { ership style }\end{array}$} & Y1.7 & 0,811 & 0,70 & Reliable \\
\hline & & $\mathrm{Y} 1.8$ & 0,810 & 0,70 & Reliable \\
\hline & & Y1.9 & 0,812 & 0,70 & Reliable \\
\hline
\end{tabular}

Source: Results of questionnaire processing using SPSS version 21 (2021) 
Based on the test results using SPSS version 21, in Table 4 the reliability test results show that all indicators of the variable have a Cronbach's Alpha value if the Deleted item is greater than 0.70 . This means that the indicators of the variables in this study are reliable.

\subsection{Technique of Data Analysis}

To analyze what has been done in the research, the researchers used the following methods:

\section{Normality test}

The normality test is a test that is useful for determining the formula to be used in hypothesis testing and to find out whether the data that has been collected is normally distributed or not. The next process in submitting a hypothesis can use parametric statistical calculations. Usually, it is said to be a large sample if the asymp.sig.2 tailed value is above 0.05 , then the data is normally distributed. In this case, data processing uses the help of the SPSS version 21 program.

\section{Qualitative Descriptive Analysis}

Qualitative descriptive analysis is a method of analysis that aims to determine the nature and deep relationship between two variables by observing certain aspects more specifically to obtain data that is in accordance with the existing problems for the purpose of research, where the data is processed, analyzed and processed more. continue with the basis of the theories that have been studied so that conclusions can be drawn from the data.

\section{Quantitative Descriptive Analysis}

Quantitative descriptive analysis is an analytical method used to analyze data from the findings of research in the field with the generally accepted scientific theory, so as to draw conclusions and evaluate the object of research. The quantitative descriptive analysis used consists of:

\section{a. Linear regression analysis}

Linear regression analysis is a data analysis method that describes the functional relationship between the dependent and independent variables.

Linear regression is used by researchers to determine whether or not there is an influence between emotional intelligence on leadership style. The regression equation used is as follows:

$\hat{\mathrm{Y}}=\mathrm{a}+\mathrm{bX}+\mathrm{e}$ .. (Suliyanto, 2011: 39)

Notes:

$\hat{Y}=$ dependent variable (Leadership Style)

$\mathrm{a}=$ Constant

$\mathrm{b}=$ coefficient of regression direction

$\mathrm{X}=$ independent variable (emotional intelligence)

$\mathrm{e}=$ Error

\section{b. Analysis of the correlation coefficient and determination}

Correlation coefficient analysis is an analysis used to determine whether or not the influence of emotional intelligence on leadership style is strong by using the correlation approach. The results of the calculation of the correlation coefficient on a strong and positive relationship can be seen in the following Table 5. 
Table 5. Criteria for Level of Relationship Between Variables

\begin{tabular}{|c|c|}
\hline Coefficient Interval & Relationship Level \\
\hline $0,00-0,199$ & Sangat Rendah (Negligible Correlation) \\
\hline $0,20-0,399$ & Rendah (Low Correlation) \\
\hline $0,40-0,599$ & Sedang (Moderately Correlation) \\
\hline $0,60-0,799$ & Kuat (Moderately High Correlation) \\
\hline $0,80-1,000$ & Sangat Kuat (High Correlation) \\
\hline \multicolumn{2}{|c|}{ Source: Sugiyono (2013:184) } \\
\hline
\end{tabular}

Furthermore, the coefficient of determination is sought, the coefficient of determination is the coefficient of determination of the contribution of variable $X$ to the fluctuation of the value of variable $Y$. To measure how much the independent variable explains the dependent variable, the coefficient of determination (KD) is used. In this coefficient shows the proportion of total variability in the dependent variable described by the regression model. The value of $R$ is in the interval $0 \leq R \leq 1$.

\section{c. Hypothesis Test: Partial test (t test)}

The $t$ test is a test conducted to determine whether the independent variable, namely emotional intelligence, and the dependent variable, leadership style, have a significant relationship or not. To find out $t$ count compared with $t$ table for error $5 \%$ or 0.05 with a confidence level of $95 \%$ or 0.95 and $d t=n-2$. In this case, data processing uses the help of the SPSS version 21 program. To determine whether it is rejected or not, the criteria are as follows:

(1) If $t$ count $>t$ table or significance $\leq 0.05$ then $\mathrm{H} 0$ is rejected, meaning that emotional intelligence has a positive and significant effect on leadership style, there is UPT Regional Revenue Management in Pematangsiantar.

(2) If $t$ count $<t$ table or significance $>0.05$ then $\mathrm{H} 0$ is accepted, meaning that emotional intelligence does not have a positive and significant effect on leadership style, there is UPT Regional Revenue Management in Pematangsiantar.

In using computerization using the statistical product and service (SPSS) software program version 21 for windows release.

\section{Data Analysis and Research Findings}

\subsection{Quantitative Descriptive Analysis}

\subsubsection{Linear Regression Analysis}

Regression analysis is a method used to describe the influence between dependent and independent variables. The researchers used regression analysis in order to determine whether or not there is influence between the independent variable $(X)$ and the dependent variable $(Y)$, where the independent variable $(X 1)$ is emotional intelligence and the dependent variable (Y) is the leadership style. By using SPSS version 21, the results of multiple linear regression testing can be obtained as shown in the following Table 6:

Table 6. Multiple Linear Regression Test Results

Coefficients $^{\mathrm{a}}$

\begin{tabular}{|c|c|c|c|c|}
\hline & \multirow{2}{*}{ Model } & \multicolumn{2}{|c|}{ Unstandardized Coefficients } & \multirow{2}{*}{$\frac{\text { Standardized Coefficients }}{\text { Beta }}$} \\
\hline & & B & Std. Error & \\
\hline \multirow[t]{2}{*}{1} & (Constant) & 10,816 & 6,041 & \\
\hline & Emotional Intelligence & ,412 & 110 &, 511 \\
\hline
\end{tabular}

a. Dependent Variable: Gaya Kepemimpinan 
Source: the results of data processing with SPSS version 21 (2021)

Based on the results of multiple regression analysis in Table 6 above, the regression equation is obtained as follows: $\hat{Y}=10.816+0.412 X$. This means that there is a positive influence between emotional intelligence on leadership style at the Pematangsiantar Regional Revenue Management Unit. Which is if emotional intelligence changes (increases) by 1 unit, then the leadership style will change (increase) by 0.412

\subsubsection{Analysis of the Correlation Coefficient and the Coefficient of Determination}

In this section, correlation aims to determine the relationship between the independent variable (emotional intelligence) and the dependent variable (leadership style). The correlation coefficient is symbolized by (r). While the coefficient of determination (KD) aims to determine the size of the contribution of the independent variable to the dependent variable, which is symbolized by (R square). Following are the results of the correlation coefficient and determination coefficient tests with the help of the SPSS version 21 program:

Table 7. Analysis of the Correlation Coefficient and the Coefficient of Determination

\begin{tabular}{|c|c|c|c|c|}
\hline Model & R & R Square & Adjusted R Square & Std. Error of the Estimate \\
\hline 1 &, $511^{\text {a }}$ &, 262 &, 243 & 3,771 \\
\hline
\end{tabular}

a. Predictors: (Constant), Emotional Intelligence;

b. Dependent Variable: Leadership style

Source: the results of data processing with SPSS version 21 (2021)

Based on the Table 7 above, the correlation coefficient with the value of $r=0.511$ is obtained, meaning that there is a moderate and positive relationship between emotional intelligence and leadership style. The coefficient of determination ( $R$ square) is 0.262 , which means that the leadership style of the UPT Regional Revenue Management in Pematangsiantar is $26.2 \%$ explained by emotional intelligence while $73.8 \%$ is explained by other factors such as communication, placement, motivation, and other variables that are not discussed. on this variable.

\subsubsection{Hypothesis Testing}

Hypotheses are temporary answers where the truth must be tested. This test is carried out partially to determine whether the hypothesis is accepted or rejected, if $t$ count $>$ $\mathrm{t}$ table or significance $\leq 0.05$ then $\mathrm{H} 0$ is rejected, meaning that there is a positive and significant influence between the independent variable and the dependent variable.

Table 8. Emotional Intelligence of Leadership Style

\section{Coefficients ${ }^{\mathrm{a}}$}

\begin{tabular}{|cc|c|c|}
\hline \multicolumn{1}{|c|}{ Model } & T & Sig. \\
\hline 1 & (Constant) & 1,790 &, 081 \\
& $\begin{array}{c}\text { Emotional Intelli- } \\
\text { gence }\end{array}$ & 3,764 &, 001 \\
\hline
\end{tabular}

a. Dependent Variable: Leadership Style

Source: the results of data processing with SPSS version 21 (2021) 
Based on the Table 8 above, the $t$ count value of the emotional intelligence variable is $3.764>$ from $t$ table with $\mathrm{dt}=\mathrm{n}-2(42-2=40) 2.02108$ or a significance of $0.000<\alpha 0.05$, then $\mathrm{HO}$ is rejected, meaning that emotional intelligence has a positive effect and significant to the leadership style at UPT Regional Revenue Management in Pematangsiantar.

\section{Research Findings}

Based on the analysis on the data, the researchers found some findings in this research, they are:

1. Emotional Intelligence at UPT Regional Revenue Management in Pematangsiantar

Based on the five dimensions used in this study, the results obtained that the emotional intelligence at the Pematangsiantar Regional Revenue Management Unit can be said to be good. This is evidenced by the results of the questionnaire which obtained good answer criteria with an average value of 3.66. However, there are still several indicators that are valued below the average value.

The dimension of self-awareness with an indicator of the leadership's ability to know the strengths of employees is rated an average of 3.05 with the answer criteria is quite good. It is better if the leadership periodically records employees so that they get an overview of the knowledge, skills and experience they have so that the delegation of tasks is more targeted. Indicators of the level of leadership confidence in their abilities are rated on average 3.64 with good answer criteria, this is necessary to maintain it by following training to increase creativity, skills and abilities so that performance results are maximized.

And in the dimension of self-regulation with indicators of the leadership's ability to maintain the norms of honesty in the agency is rated an average of 3.07 with the criteria for a good enough answer, this is better if the leadership gives sanctions in accordance with regulations to employees who accept other people's vehicle tax management with the services of brokers. While the dimension of motivation with the indicator of the ability to encourage employees to be better with an average score of 3.64 with good answer criteria, this is the leader should encourage employees more by proposing outstanding employees to the Provincial SAMSAT to raise their positions so that other employees produce maximum performance.

And the dimension of social skills with indicators of cooperation between leaders and employees with an average score of 3.64 which is a good answer criterion, this is what the leadership further strengthens harmony and friendship between leaders and employees through activities such as community outreach activities by work teams. Apart from the dimensions above, other factors need to be considered, such as the family environment and the non-family environment [14]

\section{Leadership Style at UPT Regional Revenue Management in Pematangsiantar}

Based on the results obtained from the three dimensions used in this study, the results obtained can be explained that the leadership style at the UPT Regional Revenue Management in Pematangsiantar can be said to be good. This is evidenced by the average value of 3.72 with good answer criteria. However, there are still several indicators that have a value below the average value to improve the results.

The dimensions of the democratic leadership style indicate that the technique carried out by the leader in assigning tasks for activities that are located is rated on average 3.69 with good answer criteria, to improve it, you should know the types of tasks and abilities needed and explain the procedures clearly directly to each employee.

Furthermore, the dimensions of the democratic leadership style with indicators of freedom by the leader to provide suggestions or input have an average value of 3.29 
with the answer criteria is quite good. It is better if the leadership gives the opportunity to employees to convey suggestions and ideas to the leadership.

While the dimension of leadership style is free of control with indicators of freedom of work carried out by the leadership who are in the average rating of 3.69 with good answer criteria, this should be the role of the leader as an advisor and supervisor of activities to be carried out so that employees can freely carry out their duties accordingly regulations. And the indicator of giving freedom of decision making carried out by the leadership is at an average value of 3.12 with the answer criteria is quite good. It is better if the leadership gives the opportunity for employees to be independent in making decisions both individually / in groups by providing guidance on how to make good decisions.

In addition to the above dimensions, to improve leadership style, it is necessary to pay attention to the role of leadership. The role of leadership functions to influence subordinates to carry out their duties optimally, namely the role of instruction, the role of consultation, the role of participation, the role of delegation and the role of controller [15].

\section{Conclusions}

Based on the descriptions that have been stated in the previous points, conclusions can be made, namely:

1. The results of qualitative descriptive analysis on emotional intelligence are good. Then the highest value on the dimension of self-regulation with indicators of selfcontrol of emotions owned by the leader. And the lowest score in the dimension of self-awareness with the indicator of the leadership's ability to know the strengths of employees. So, it can be concluded also in terms of emotional intelligence, leaders have good self-control, have high empathy and are able to motivate employees to work.

2. The results of the qualitative descriptive analysis of the leadership style are good. Then the highest score is in the dimension of the autocratic leadership style, namely the indicator of dictating the work tasks carried out by the leader. While the lowest value is in the dimension of control-free leadership with indicators of giving the leadership freedom of decision-making. From the description, it can be concluded that the tendency of leadership style in the Pematangsiantar Regional Revenue Management Unit is autocratic leadership. This can be seen from the ability to dictate tasks, the tendency to reject suggestions from employees and the lack of independence of employees in making decisions

3. The results of linear regression analysis indicate that there is a positive influence between emotional intelligence on leadership style at the UPT Pematangsiantar Regional Income Management either simultaneously or partially.

4. The results of the correlation coefficient analysis show that there is a moderate and positive relationship between emotional intelligence and the leadership style of the Pematangsiantar Regional Revenue Management Unit.

5. The results of partial hypothesis testing ( $\mathrm{t}$ test), $\mathrm{H} 0$ is rejected, meaning that emotional intelligence has a positive and significant effect on leadership style in the UPT Regional Revenue Management in Pematangsiantar partially. 


\section{References}

[1] Bangun, W. Manajemen Sumber Daya Manusia. Jakarta: Erlangga. 2012

[2] Julyanthry. Pengaruh Kepemimpinan dan Budaya Organisasi Terhadap Kompetensi Guru SMP Sultan Agung Pematangsiantar dengan Motivasi Sebagai Moderating Variabel. SULTANIST: Jurnal Manajemen dan Keuangan. 2016. 4 (1), PP. 23-38. DOI: https://doi.org/10.37403/sultanist.v4i1.61. Retrieved from: https://sultanist.ac.id/index.php/sultanist/article/view/61

[3] Caniago, C.; Siregar, R. T.; Julyanthry.; Pakpahan, G. E. Pengaruh Kualitas Pelayanan dan Harga Terhadap Kepuasan Konsumen dengan Brand Image Sebagai Variabel Moderating pada Toko Sinar Bintang Photo Pematangsiantar. SULTANIST: Jurnal Manajemen dan Keuangan. 2019. 7 (2), PP. 21-31. DOI: https://doi.org/10.37403/sultanist.v7i2.151. Retrieved from: https://sultanist.ac.id/index.php/sultanist/article/view/151

[4] Darlita, E. Pengaruh Kompetensi Manajerial dan Kecerdasan Emosional Terhadap Gaya Kepemimpinan Pejabat Administrasi di Provinsi Jambi. Badan Pengembangan Sumber Daya Manusia Provinsi Jambi. Jurnal Kebijakan Pembangunan. 2019. Volume 14 No. 1. Retrieved from: https://www.jkpjournal.kalselprov.go.id/index.php/menu/article/view/12

[5] Effendi, U. Asas Manajemen. Edisi II. Cetakan kedua. Jakarta: Rajawali. 2015.

[6] Enggana, J.; Lie, D.; Efendi.; Julyanthry. Pengaruh Budaya Organisasi dan Disiplin Kerja Terhadap Produktivitas Kerja Karyawan pada PT. Bank Mestika Dharma, Tbk. Cabang Pematangsiantar. SULTANIST: Jurnal Manajemen dan Keuangan. 2017. 5 (1), PP. 11-20. DOI: https://doi.org/10.37403/sultanist.v5i1.80. Retrieved from: https://sultanist.ac.id/index.php/sultanist/article/view/80

[7] Tanzil, C. T.; Lie, D.; Efendi.; Julyanthry. Pengaruh Likuiditas dan Leverage Terhadap Profitabilitas pada Perusahaan Sub Sektor Industri Barang Konsumsi yang Terdaftar Di Bursa Efek Indonesia. SULTANIST: Jurnal Manajemen dan Keuangan. 2017. 5 (2), PP. 10-17. DOI: https://doi.org/10.37403/sultanist.v5i2.90. Retrieved from: https://sultanist.ac.id/index.php/sultanist/article/view/90

[8] Indriyanti, L. Pengaruh Kecerdasan Emosional terhadap kepemimpinan dan organisasi. STIE Pelita Nusantara Semarang. Jurnal Fokus Ekonomi. 2009. Volume 4, No. 2. Retrieved from: http://www.stiepena.ac.id/wp-content/uploads/2012/11/penafokus-vol-4-no-2-40-45.pdf

[9] Sugiyono. Metode Penelitian Kuantitatif, Kualitatif dan R\&D. Bandung: Alfabeta. 2013.

[10] Ikhsan, A.; Tarigan, N. M. R.; Zakhyadi, A. Perilaku Organisasi (Organizational Behavior). Cetakan Pertama. Bandung: Cita Pustaka Media. 2015.

[11] Mulyadi, D. Perilaku Organisasi dan Kepemimpinan Pelayanan (Konsep dan Aplikasi Administrasi, Manajemen dan Organisasi Modern). Cetakan Kesatu. Bandung: Alfabeta. 2015.

[12] Tohari, H. Gaya Kepemimpinan Berbasis Emotional Intelligence. Institut Agama Islam Negeri Purwokerto. Jurnal Kependidikan. 2017. Volume 5, No. 1. Retrieved from: http://ejournal.iainpurwokerto.ac.id/index.php/jurnalkependidikan/article/download/1241/942

[13] Wirawan. Kepemimpinan: Teori, Psikologi, Perilaku Organisasi, Aplikasi dan Penelitian. Edisi I. Cetakan Kedua. Jakarta: Rajawali Pers. 2014.

[14] Goleman, D. Kecerdasan Emosional: Mengapa EQ Lebih Penting Daripada IQ. Edisi Revisi Kedua. Cetakan Kedua. Jakarta: Gramedia Pustaka Utama. 2018

[15] Rivai, V. Kepemimpinan dan Perilaku Organisasi. Edisi II. Jakarta: PT Raja Grafindo Persada. 2012 